\title{
低速電子照射で生成する $\mathrm{Si}$ 表面欠陥
}

\author{
中山 幸仁 ${ }^{* 1, * 2} \cdot$ John H. WEAVER ${ }^{* 2}$
}

（受理1999年 7 月 8 日，掲載決定1999年 8 月 7 日）

\author{
Electron-Stimulated Modification of Si Surfaces* \\ Koji NAKAYAMA*1,*2 and John H. WEAVER ${ }^{* 2}$ \\ *2 (Department of Materials Science and Chemical Engineering University \\ of Minnesota, Minneapolis, MN 55455, USA)
}

(Received July 8, 1999, Accepted August 7, 1999)

\section{1. はじめに}

10-5000 eV の電子は，固体表面分析法で非破壞分析 として最も一般的に用いられているプローブである. 非 破壊分析の例外として，ガス原子が吸着した金属表面や 酸化物, 有機物などの化合物表面に対する電子照射損傷 は, 電子刺激脱離 (ESD) として良く知られている1,2). しかしながら, 驚くべきことに清浄表面の単体原子と, これらの低ェネルギー電子との相互作用の有無を確認す る研究報告はなく, これまで相互作用は無いと黙認され ていた. 本稿で紹介する研究は, 原子分解能を持つ超高 真空走査トンネル顕微鏡 (STM) を用いて, 電子照射 が効果的に半導体表面を損傷することを報告する ${ }^{3)}$. こ の結果は, 低速電子線回折 (LEED) やオージェ電子分 光法（AES）で得られた測定結果の再現性を保つため に, 電子照射量に細心の注意を必要とするといらことの みならず, 電子ビームは化学物質の代わりに半導体表面 のエッチングに使用できる可能性があることを示してい る.

本稿では, 走査トンネル顕微鏡の探針操作ならびにレ ーザー照射による原子移動など最近行われた研究の報告 を紹介しながら, 電子照射で起こる欠陥生成と原子移動 のメカニズムを考察する. Si $(100)$ 表面では, 欠陷増加

\footnotetext{
* Phys. Rev. Lett., 82 (1999) 980亿揭載.

*1 現所属 : 東北大学金属材料研究所（宁980-8577 仙台市青葉区片平 21-1)

*2 ミネソタ大学 (55455, ミネアポリス, ミネソタ州, アメリカ)
}

率が電子露出に依存して増加することを求め, また, 欠 陥から真空中への原子の脱離や原子がテラス上へ移動し て堆積することを実証した。また，Si(111)表面では， Si $2 \mathrm{~s}$ と $2 \mathrm{p}$ の内殼励起のしきい值に関係なく, 欠陥生成 率は電子ェネルギーと共に単調に増加することが求めら れた。 これは, 内殼励起は重要でなく, 非弾性的なカス ケード散乱が久陥生成に寄与するためと考えられる.す なわら, 散乱電子は価電子帯電子を非占有状態へ励起す るか, またはその散乱過程中に非占有状態に共鳴して捕 獲される.これらの励起状態からの緩和が原子結合切断 に関与すると推定する. また, 表面の面方位の違いは, 単位電子当たりの欠陥生成率が異なり, 久陥生成と原子 移動過程の傾向の違いを反映している.

\section{2. 実験方法}

実験は, 各々独立に排気されたSTM真空槽と, LEED, AES 電子銃ならびに試料加熱機構付のマニュピ レーターを備えた準備真空槽 $\left(7 \times 10^{-9} \mathrm{~Pa}\right)$ の中で行わ れた. 実験条件, 試料清浄化法については, 文献を参照 していただきたい3).

電子照射で $\mathrm{Si}$ 表面上の不純物（主に炭素や酸素）が 増加してくることはAESの実験により報告されてい る4). 今回の実験で用いた最大電子露出条件で表面上の 炭素濃度は, AES の C-KLL と Si-LVV ピーク強度比 から求めてみると $1 \%$ 以下であった. また, 酸素の比率 はさらに少なかった.ささらに, AES で検出不可能な水 素の影響を調べるため, 以下の実験を行った. 
電子銃を起動すると真空度が $3 \times 10^{-8} \mathrm{~Pa}$ まで上昇す る.これは, 電子銃近傍がフィラメントで爰められて, 水などの残留ガスが微量に放出され続けるためであると 考えられる. 表面への影響を調べるため, 電子銃のア, ードバイアスを印加しないで（フィラメントだけが加熱 して電子は放出されない), 清浄表面を電子銃の前に曝 した，その結果， $\mathrm{Si}(100)$ 表面では, 150秒の露出で $\mathrm{c}$ 型 欠宿5)の約 4\%の増加が認められたが, $\mathrm{Si}(111)$ 表面では, 20分以上の露出を行っても際立った構造変化はなかっ た。

電子の露出量と分布は, ファラデーカップを用いて各 々の入射エネルギー值に対して測定した. STM 探針の アプローチの簡便化のため, 電子線はレンズで広げ試料 の中心に照射した．その中心の電子照射領域外の点を走 査してみたが, 欠陥の増殖は確認できなかった。

以上の結果から, 久陥生成は, 電子照射が本質的であ り, 残留ガスは関与していないと結論した.

\section{3. 実験 結 果}

$3.1 \mathrm{Si}(100)-2 \times 1$ への電子照射と回復

図 1(a)は, 電子照射前の清浄な $\mathrm{Si}(100)-2 \times 1$ であ る.ダイマー配列の方向の違いによって, 直線的な $\mathrm{S}_{\mathrm{A}}$ ステップと歯状的な $\mathrm{S}_{\mathrm{B}}$ ステップが現われる. 右上の挿 入図は, ステップ付近の原子分解能で得られた STM 像 である。ダイマー欠陥 (DV) ならびに, c 型欠陥 (CD) が示してある.ステップ端ならびに, 久陷近傍 では, 占有状態の STM 像で良く見らるよらに, 非対称 なダイマーが観測されている. 熱サイクルによる試料清 浄化後に, 初期欠陥は最大で約 $4 \%$ 存在した ${ }^{6)}$.

図 1(b)は, 室温で $2000 \mathrm{eV}, 6.4 \times 10^{16} \mathrm{~cm}^{-2} \mathrm{~s}^{-1}$ のフラ ックスで150秒照射後のSTM像である. 暗い欠陥の特 徵が増加していることが明白に分かる. ダイマー欠陥 は, 露出時間が 100 秒近辺まで線形に $0.14 \mathrm{ML}$ まで増加 する. その後, さらに増加率は増大して150秒後には,

$0.24 \mathrm{ML}$ まで欠陥面積は増える。この電子照射で最大 で約 $4 \mathrm{~nm}$ の成長した欠陥を観測した．欠皕が成長する 理由として, 平滑なテラスよりも欠陷で電子散乱が起こ り易く, その結果, 電子励起がそこに局在して起こるこ とが予想できる．また，原子の脱離エネルギーが欠陥の 境界で減少していることも，この欠陷成長槣与してい ると考兄られる. 欠陥密度は電子の照射量の増加ととも に注活線形に増加しする。これは欠宿がランダムに生成 することを示している．また，テラス上に最大で約 2 $\mathrm{nm}$ 程度の大ささを持つ, 明るい原子集合体が観測され た.これらは, 以下に述べるょらに, 久陥から移動した $\mathrm{Si}$ 原子である. 図 1(b)の表面を873 K で，2 分間加熱す
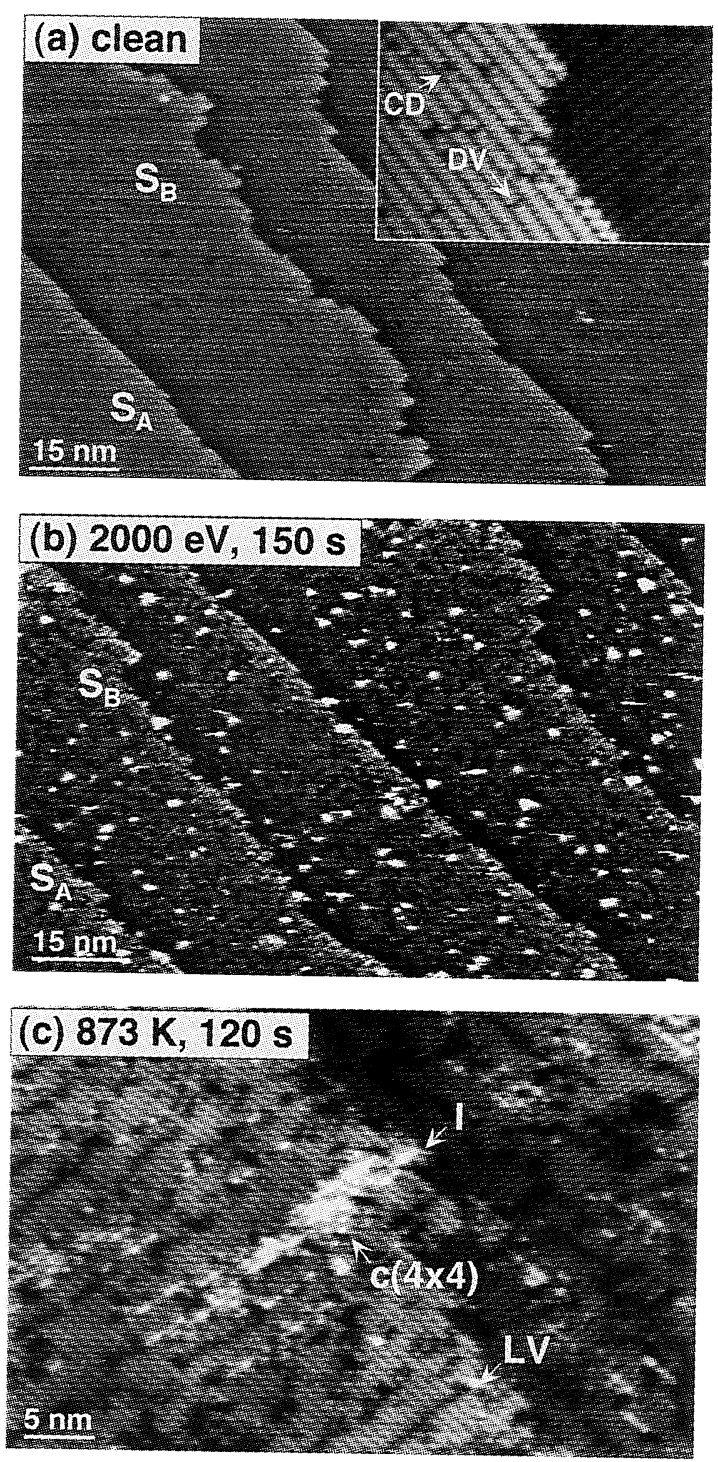

図 1 (a)サンプルバイアスが- $2.0 \mathrm{~V}$ で, トンネ ル電流が $0.2 \mathrm{nA}$ で得られた清浄な $\mathrm{Si}(100)$ 一 $2 \times 1$ の STM 像. 直線的な $\mathrm{S}_{\mathrm{A}}$ ステップと歯 状的な $\mathrm{S}_{\mathrm{B}}$ ステップが交互に現われる。挿入 図は，原子分解能で得られたステップ近傍で ある.ダイマー久陥， $\mathrm{c}$ 型欠陷はそれぞれ DV, CD と付記されている.

(b) $2000 \mathrm{eV}$ の電子で150秒間照射した後の STM 像. 黒い欠陥の特徵が増大している. また，白い特徵で現れる原子群が，表面にラ ンダムに存在している。

(c) (b)のような $2000 \mathrm{eV}$ の電子で損傷を受け た表面を $873 \mathrm{~K}$ で 2 分間加熱した後の STM 像. 表面の付加原子はエピタキシャル成長し て, 基板のダイマー列之直角に島状に整列す る。また，ダイマー欠陥も線状に配列してい るのも確認できる. 
ると，図1(c)に示しているよらなダイマー列と直交し て成長するアイランド（I）が観測された。これは Lagallyらによって報告されたよらな, $380 \mathrm{~K}$ 以上で $\mathrm{Si}(100)$ 上に $\mathrm{Si}$ を蒸着してェピタキシャル成長させた, $\mathrm{Si}$ アイランドの特徵的な構造と同一なるのである7). た，Zhangらは，ステップ端やエピタキシャル成長した アイランドの端に出現する特徵的な $\mathrm{c}(4 \times 4)$ ドメイン 構造を確認した ${ }^{8)}$. 図1(c)に示してあるように，この $\mathrm{c}(4 \times 4)$ 構造も電子照射表面を加熱することで出現す る.したがって, 電子照射後に不純物ではなく, Si 原 子が表面に堆積していることが分かる.

Zandvliet らは，Si(100)-2×1に $\mathrm{Ar}^{+}$イオン照射した 後に873-1123 K で加熱した後，ダイマー列に直交して 各々のダイマー欠陥が配列する，いわゆるライン欠陷を STM で観測している ${ }^{9)}$. Metiu らは, 隣り合ったダイ マー列に存在する欠陥同士の相互作用を求め, このライ ン欠陷配列がエネルギー的に優位になることを求めた ${ }^{10)}$. 図1(c)に示してあるように，電子照射で生成したダイ マー欠陷も，加熱によってライン欠陥（LV）を形成す ることが判明した。

\section{$3.2 \mathrm{Si}(111)-7 \times 7$ 表面上での欠陥生成のエネルギー} 依存性

$\mathrm{Si}(111)$ でも $\mathrm{Si}(100)$ と同様に，電子露出量に依存した 欠陥増加が測定されたが，ここでは露出量が一定（2× $\left.10^{18} \mathrm{~cm}^{-2}\right)$ で，入射エネルギーを変化させたとさの欠 陷増加量を求めた。図 2(a) は90 eV, 図 2(b)は2000 eV の電子照射後の STM 像である. 図2(a)の右上の挿入 図は，清浄な $\mathrm{Si}(111)-7 \times 7$ 表面である。非占有状態の STM 像は, $7 \times 7$ 単位格子内に, 黒いコーナーホールに 隣接したコーナーアドアトムとセンターアドアトムを描 き出す。アドアトムの欠陷濃度は, $90 \mathrm{eV}$ の電子露出 $(0.5 \mu \mathrm{A}, 20$ 分間）で $2 \%$ 増加し， $2000 \mathrm{eV}$ の露出（1.2 $\mu \mathrm{A}, 500$ 秒間）では，10\%増加した. 図2(c)に示される ように, 久陷濃度は入射ェネルギーに依存して単調に増 加している. もし内壳準位励起が欠陥生成に寄与してい るならば, Si $2 \mathrm{~s}$ と $2 \mathrm{p}$ 付近 $(\sim 100,150 \mathrm{eV})$ でその収量 は二次電子生成の効果のため緩やかに減少するはずであ る。また，欠陥増加量は少ないがこれらの準位以下の入 射エネルギー $(90 \mathrm{eV})$ で欠陥が増殖している．したが って，内殼励起が関連するオージェ遷移過程などは，欠 陷生成に寄与していないと思われる。

センターアドアトム欠陷はコーナーアドアトム欠陷に 対して1.2倍の割合で発生し，欠陷は積層欠陷側に1.3倍 の割合で現れた. $2000 \mathrm{eV}$ の電子照射後は, 約半数の欠 陷が欠陥成長していることが確認され，最大で 7 個のア ドアトムが喪失した大きな欠陥が出現した．この欠陷成
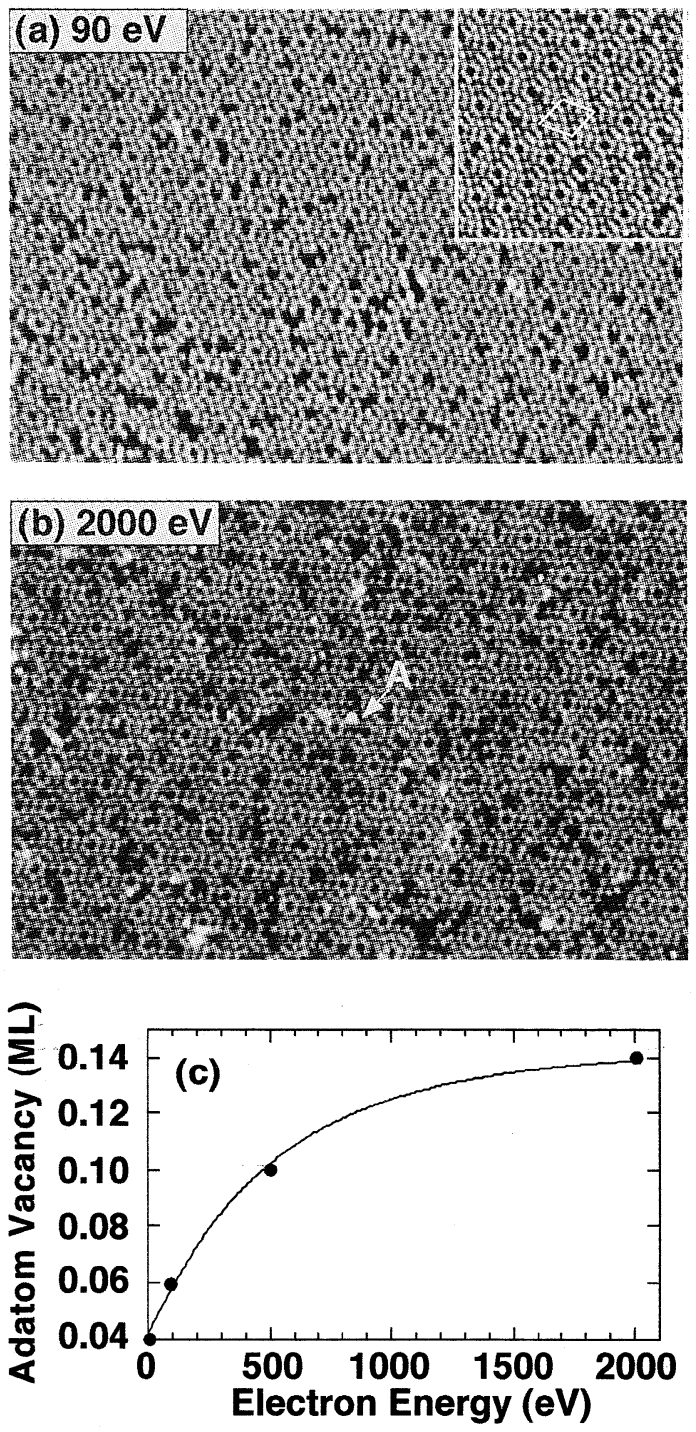

図 2 電子露出量を一定 $\left(2 \times 10^{18} \mathrm{~cm}^{2}\right)$ にして照射 したときの $\mathrm{Si}(111)$ 表面の変化.（a） $90 \mathrm{eV}$, (b) $2000 \mathrm{eV}$ の電子照射後の STM 像である. (a)の扦入図は清浄な $\mathrm{Si}(111)-7 \times 7$ を比較の ため示してある.サンプルバイアスが $1.7 \mathrm{~V}$

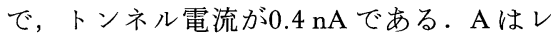
ストアトムの上にある Si 原子と思われる. (c) $\mathrm{Si}$ (111) 表面上のアドアトム欠陷のエネ ルギー依存性.

長の傾向は $\mathrm{Si}(100)$ と同様で, はじめにランダムに生成 した欠陥は，電子の露出時間と共に各々の欠陥が成長す る傾向を示す. 図 2(b)の A は, その吸着位置から判断 すると，放出された Si 原子が，レストアトムのダング リングボンドに捕獲されているものと考えられる. 
$\mathrm{Si}(111)$ 表面からの原子移動の断面積は, $90 \mathrm{eV}$ の電子 照射では, $1 \times 10^{-20} \mathrm{~cm}^{2}$ であり, $2000 \mathrm{eV}$ では $5 \times 10^{-20}$ $\mathrm{cm}^{2}$ であった。 これらの值は, 吸着表面からの典型的な

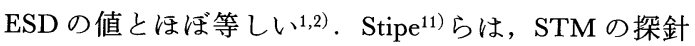
を用いて $\mathrm{Si}(111)$ 表面に欠陷を作り，そこから移動した Si 原子を追尾する観測を行った. その結果, $175 \mathrm{~K}$ 以上 ではアドアトム層の欠陥の寿命が短いという報告をして いる.したがって，ここで見積もりを行った原子移動の 断面積值は過小評価である.すなわち, 図 2(b)のAの ような, 電子照射でテラスに移動した Si 原子の多くの ものは, 室温で容易に拡散して欠陥に入り込むので, 久 陥が生成しても見かけ上は何も変化のない構造を示すた めである.

$\mathrm{Si}(100)$ 表面第一層の原子はダイマーを形成するため, 欠陥の生成過程は $\mathrm{Si}(111)$ とは異なる. ダイマー久陷を 修復するためには，同時に 2 個の原子がその欠陥内に捕 獲されなければならないので, 修復する確率は非常に低 い.したがって，この修復効果は無視することができ， $2000 \mathrm{eV}$ での欠陥生成の断面積は $1.2 \times 10^{-20} \mathrm{~cm}^{2}$ である. また, 表面上に移動した原子の総面積は, 欠陥の総面積 の約 $20 \%$ 程度であるので, 真空中への原子脱離が頻繁に 起こることがわかる.

\section{4. 考察}

電子照射で起こる欠陥生成と原子移動のメカニズムは 何であろらか？ ヒントは最近行われたレーザー照射に よる損傷実験やSTM の探針を用いた原子移動から得ら れる. 金崎 ${ }^{12)} ら は ， 23-150 \mathrm{~mJ} / \mathrm{cm}^{2}$ のレーザーを用いて $\mathrm{Si}(111)-7 \times 7$ から Si 原子の脱離を測定している. フォ トンのエネルギーが約 $2 \mathrm{eV}$ のき, アドアトム層から の原子脱離が最大になることが示された.この結果は, 表面の占有状態から非占有状態への双極子遷移が原子脱 離に重要であることを示している.イリノイのグループ は13), STM 探針から放出される電子を用いて, Si(100) 表面に吸着した水素を脱離させた。 その結果, $6 \mathrm{eV}$ の 電子によって励起される $\sigma \rightarrow \sigma^{*}$ 遷移が脱離に寄与してい ることが判明した．同様にSTM 探針を用いた Stipe ら の実験では11), センターアドアトムがテラス上へ移動す ることによる久陷生成は, 局在した非占有状態 $\sigma^{*}$ に電 子が捕獲されることが重要な過程であると報告してい る. IBM のグループは, $\mathrm{Si}(111)$ 表面上の酸素の移動に ついても非占有状態に電子が共鳴捕獲されることで酸素 原子の移動機構を説明している14).

$\mathrm{Si}(100)$ 表面に関して，2.48 eV のレーザー照射では

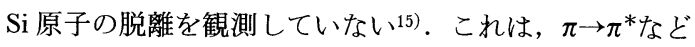
の浅い遷移はダイマー結合の切断に関与していないこと
を意味している.このダイマー結合を切断するには，よ り深い準位の遷移, すなわち, 価電子帯上端から〜3 $\mathrm{eV}$ 下の $\sigma$ 準位から, 伝導帯下端付近の $\sigma^{*}$ 準位への遷移 が重要になると考えられる.

我々の用いた電子は90-2000 eVのエネルギーを持つ ので, 表面に入射した電子は, バルクに向かって非弾性 のカスケード散乱を繰り返しながら，比較的広い領域に ホットキャリアを作り出す。この中のいくつかの電子は 電子一正孔を作り出し，これらの消隇エネルギーの一部 を利用して原子移動が起こる. また, 電子が散乱過程中 に，表面の非占有状態に共鳴するとき，そこに電子は捕 獲される，その捕獲電子を収容するために，原子位置は 変位させられるはずである．この位置変化は，原子脱離 や表面上への原子移動を容易にする可能性があり, 結果 として原子結合の切断を生ずると考えられる.

我々が発見した欠陥生成は，Si 表面に特有のもので はない，超高真空中で䢃開した GaAs(110)表面には， 欠陷密度の低い平滑な表面が現れることが知られてい る. この表面に対して電子照射を行い， $\mathrm{Si}$ 表面と同様 な, ランダムな欠陥生成やテラス上に移動した原子を STM で観測した．さらに，この電子損傷を受けた表面 に, $2.3 \mathrm{eV}$ のレーザーを照射すると, これらの欠陥は 欠陥周囲から原子が脱離して久陥が成長することを観測 した．この結果は， $\mathrm{GaAs}(110)$ 表面でも電子照射で欠陥 生成が可能であり，フォトンの照射量を調整すること で，欠陥の大きさを制御することも可能であることを示 している16).

\section{5. 結論}

シリコンとガリウムヒ素表面上に，一般的に LEED と AES で用いられる電子ビーム照射の条件で, 表面の 欠陥が増殖することを STM で求めた.

昨年, フランスの CAE 研究所の Ernst らは, レーザ 一照射によって銅単結晶表面上で銅原子が移動すること を報告している17)。これは電子励起を起因とする原子移 動が，半導体表面のみならず金属表面でも可能であるこ とを示している. これらの結果は, 化学物質を用いるこ となしに固体表面のエッチングの可能性を示し，また， 生成した欠陥を媒体とした表面反応の新しい応用分野を 開拓するものとして期待できる.

\section{[文献]}

1) R. D. Ramsier and J. T. Yates, Jr.: Surf. Sci. Reports, 12 (1991) 243.

2) T. E. Madey and J. T. Yates, Jr.: J. Vac. Sci. Technol., 8 (1971) 525.

3) K. Nakayama and J. H. Weaver: Phys. Rev. Lett., 
82 (1999) 980.

4) C. J. Powell and M. P. Seah: J. Vac. Sci. Technol., A 8 (1990) 735.

5） c 型欠陥はダイマー列に沿って 2 個の単体 Si 原子 欠陥が配列するモデル [R. J. Hamers and U. K. Kohler: J. Vac. Sci. Technol., A 7 (1989) 2854; Z. Zhang, M. A. Kulakov and B. Bullemer: Surf. Sci., 369 (1996) L131.]があるが， 2 層目の原子欠陷やその位置に水 素が吸着したモデル [K. Terakura, T. Uda, T. Yamasaki and T. Miyazaki: Surf. Sci., 358 (1996) 394.] や, OH 基の吸着モデル [M. Chander, Y. Z. Li, C. Patrin and J. H. Weaver: Phys. Rev. B, 48 (1993) 2493.] も提案されている.

6) B. S. Swartzentruber, Y.-W. Mo, M. B. Webb and M. G. Lagally: J. Vac. Sci. Technol., A 7 (1989) 2901.

7) Y. M. Mo, J. Kleiner, M. B. Webb and M. G. Lagally: Phys. Rev. Lett., 66 (1991) 1998.

8) Z. Zhang, M. A. Kulakov and B. Bullemer: Surf. Sci., 369 (1996) 69.

9) H. J. W. Zandvliet: Surf. Sci., 377-379 (1997) 1.

10) P. C. Weakliem, Z. Zhang and H. Metiu, Surf. Sci., 336 (1995) 303.
11) B. G. Stipe, M. A. Rezaei and W. Ho: Phys. Rev. Lett., 79 (1997) 4397.

12) J. Kanasaki, T. Ishida, K. Ishikawa and K. Tanimura: Phys. Rev. Lett., 80 (1998) 4080.

13) T.-C. Shen, C. Wang, G. C. Abeln, J. R. Tucker, J. W. Lyding, Ph. Avouris and R. E. Walkup: Science, 268 (1995) 150; See also R. S. Becker, G. S. Higashi, Y. J. Chabal and A. J. Becker: Phys. Rev. Lett., 65 (1990) 1917; M. Schwartzkopff, P. Radojkovic, M. Enachescu, E. Hartmann and F. Koch: J. Vac. Sci. Technol., B 14 (1996) 1336.

14) M. Martel, Ph. Avouris and I.-W. Lyo: Science, 272 (1996) 385.

15) K. Ishikawa, J. Kanasaki, Y. Nakai and N. Itoh: Surf. Sci. Lett., 349 (1996) L153. 日本語の解説は, 伊藤憲昭, 金崎順一, 岡野晃子, 中井靖男, 応用物 理，第64巻，第 6 号，1995年，536がある.

16) B. Y. Han, K. Nakayama and J. H. Weaver: Phys. Rev. B (in press).

17) H.-J. Ernst, F. Charra and L. Douillard: Science, 279 (1998) 679. 